\title{
Perceptions of Different Generations Regarding Managerial Competencies in Restaurants
}

\author{
Carina Kleynhans, Malome Prince Shai, Antoinette Roeloffze \\ Faculty of Management Sciences, Tshwane University of Technology, South Africa \\ kleynhansic@tut.ac.za, shaimp@tut.ac.za, roeloffzea@tut.ac.za
}

\begin{abstract}
Managerial competencies of restaurant managers play a major role in motivating employees to be productive and to provide excellent service which, in turn, will lead to customer satisfaction. Drawing upon generational differences in work ethics and values, the authors examine the importance of managerial competencies in three age cohorts. A quantitative research design was selected using a structured questionnaire consisting of five competency domains. Data were collected from 180 restaurant managers and employees in restaurants in the City of Tshwane. The results of the Fisher exact test indicated that the importance of managerial competencies differed significantly in the three age groups. Significant differences existed for three leadership domains, two management domains, one interpersonal and one intrapersonal domain. No significant differences were recorded for the perceptions of the different age groups regarding the importance of the technical domain. For the younger generation, the ability to grant employees the opportunity to grow was regarded as highly important by all respondents. The ability to maintain discipline in the workforce was perceived as less important by the youngest age group when it was compared to the other age groups. The youngest employees felt that the ability to be innovative was not as important unlike the perception of the older age groups. The findings of this study could lead restaurant managers to a better understanding of the different generational groups, how to motivate them thereby ensuring job satisfaction and service quality.
\end{abstract}

Keywords: Generations, Restaurant industry, Managerial competencies, Job satisfaction

\section{Introduction}

The tourism and hospitality industry continues to be one of the fastest-growing and most vibrant sectors of Africa's economy, contributing 9\% to South Africa's GDP in 2015 (Price Waterhouse Coopers, 2016). As the restaurant segment is a key source in the service sector in generating income in many African countries, factors affecting restaurant performance, such as management competencies, need to be explored(Voon, de Jager, Chitra, Kueh, \& Jussem, 2013). These management competencies are the signal from a hospitality establishment to indicate the areas and levels of performance that the establishment expects from their employees. Currently, the hospitality industry is experiencing major environmental and market changes such as increasing levels of competition, rising costs accompanied by falling margins due to static prices, an inability to raise the necessary capital as well as changing customer and employee attitudes(Suh, West, \& Shin, 2012) and the increased turnover requirements to remain viable(Brown, Thomas, \& Bosselman, 2015; Kim, 2014; Streeter, 2007). Managers need to possess the appropriate competencies to adapt to these and other unforeseen environmental demands within a dynamic operating environment (Suh et al., 2012) to ensure success in the hospitality industry (Riggs \& Hughey, 2011).Today's work environment calls for creativity, confidence, assertiveness and team-building skills if success is to be ensured(Vijayalakshmi, 2016). Providing a set of management competencies will not only assist the employee with a map of behaviours, but with skills that will be valued, recognised and rewarded in the establishment. These management competencies will be explored in this paper.

To meet the requirements of the rapidly changing hospitality industry, it is imperative to determine which competencies are essential (Sisson \& Adams, 2013) and to ensure that future management possess these competencies (Suh et al., 2012; Vijayalakshmi, 2016). Due to the current turbulent economic conditions, human capital is becoming a critical factor in hospitality establishments, such as restaurants. If these establishments are able to manage their human capital they will stand a chance of success in the industry. Studies show that there is strong evidence to indicate that infusion of human capital development promotes innovation, as well as better performance ((Neagu, Lazar, Teodoru, \& Macarie, 2016). Innovation and performance depend on a work environment that attracts, meets and even exceeds the employee's expectations. How the employee feels about the work environment will depend on his or her characteristics. Having a set of competencies are an important management tool and applied intelligently can be used to drive 
up performance of the employee, retain valuable resources and inform restructuring in an establishment that will positively impact outcomes. An employee's commitment to a job is determined by his or her perception of and attitude towards work in a specific industry(Richardson, 2010).

Major generational demographic shifts are occurring in the hospitality workforce (Chi, Maier, \& Gursoy, 2013), with large numbers of Baby boomers leaving the workforce resulting in the loss of valuable experience and knowledge (Dannar, 2013). Generational membership directly affects level of work engagement and turnover intention (Park \& Gursoy, 2012). It can be assumed that younger employees' psychological characteristics such as high self-esteem and optimism could drive them to feel more psychologically involved at work (Kowske, Rasch, \& Wiley, 2010), which situation could lead to a higher level of satisfaction (Park \& Gursoy, 2012) with lower turnover intention (Chi et al., 2013). Today's hospitality workforce is characterised by multigenerational teams. Multigenerational differences in views and perspectives can lead to conflict, resulting in high employee turnover with inevitable decreased productivity (Yang \& Guy, 2006). With the influx of younger employees into the hospitality industry, managers are faced with fresh challenges. Operational managers need to update their knowledge of what motivates their employees to ensure good service delivery and low staff turnover (Brown et al., 2015). From the above introduction it is clear that the importance of this study lies in the provision of the necessary knowledge for managers to assist them in managing the new workforce meaningfully. It further provides training institutions with information that should be included in their curricula. This study sought to answer the following question: 'Does the importance attached to competencies differ significantly in different age groups?'

\section{Literature Review}

The literature review is divided into two sections. In the first section, managerial competencies are summarised. The second section relates to the selected generational groups.

Managerial competencies: Three general perspectives on competency theory have emerged in the literature, namely: competencies as individual characteristics; competencies as characteristics of organisations; and competencies as a tool to facilitate and structure communication between education and the labour markets (Kalargyrou \& Woods, 2011; Mahachi, 2012). Millar, Mao, and Moreo (2010) and Porter (2005)postulate that the Competency Domain Model developed by (Sandwith, 1993) is the most reliable and influential competency model available in today's business environment. It identifies five competency domains: a leadership domain, a conceptual domain, an interpersonal domain, an administrative domain, and a technical domain. Managerial competencies can be used to recognise and address trends, challenges and developments in the service industry, specifically in restaurants. Furthermore, they can be applied to provide the knowledge, skills and abilities required by successful managers and leaders in each segment of the hospitality industry (Koenigsfeld, Perdue, Youn, \& Woods, 2011). Some organisations use competencies as a benchmark to compare the skills an individual has with the skills the individual needs to fill a particular position. Relevant managerial competencies enable managers to get to know the organisation as a whole, lead and manage people, communicate effectively and manage the available resources to achieve the restaurant's objectives, missions and goals (Aguinis, Gottfredson, \& Joo, 2012). As the hospitality industry is labourfocused and people-oriented, the concept of competency management should be stringently adhered to. Only when managers and employees are fully competent to perform their appointed tasks will their level of job satisfaction increase, resulting in positive outcomes for those restaurants (Shai, Kleynhans, \& Roeloffze, 2016).Possessing social competencies or soft skills is essential in the hospitality industry because service orientation in the restaurant industry is bolstered by service encounters which are social in nature (Louw, Pearse, \& Dhaya, 2012). Social competencies include communication skills, conflict resolution (Kay \& Russette, 2000), social awareness and motivation of people (Cherniss \& Goleman, 2001; McKenna, 2004). Firdauz, Sapri, and Mohammad (2015) maintain that organisations and managers will certainly encounter difficulties if they lack leadership and management competencies.

Leadership domain: Koenigsfeld et al. (2011)isolate the leadership domain as being the most important and frequently cited competency cluster. As effective leadership is the ultimate goal that many organisations strive for, commitment to the development of managers' skills and competencies is imperative (McCarthy \& Garavan, 2007). Leadership can be regarded, at best, as the cardinal asset in the restaurant business or, at 
worst, as its most serious liability (Singh, 2008). Jauhari (2009) and Firdauz et al. (2015) state that leadership skills such as participative decision-making, critical thinking, problem- solving, and the ability to instil commitment are critical to an organisation's future because they directly improve the level of responsiveness to customer needs. Leadership skills have become increasingly important in the running of hospitality corporations (Koenigsfeld, Youn, Perdue, \& Woods, 2012). Implications of a lack of leadership skills could lead to business failure, low productivity and an inability to respond to market changes and uncertainty. On the other hand, strong leadership in the restaurant sector plays a major role in achieving high profitability and productivity as well as competitive advantage.

Management domain: The management domain refers to those skills that relate to articulating goals, organising employees, allocating resources, monitoring progress and empowering employees with knowledge and skills (Weber, Finley, Crawford, \& Rivera, 2009). The management domain enables managers to know the organisation as a whole, lead and manage people, communicate effectively and manage available resources to achieve the restaurant's objectives, missions and goals. Managers bear the key responsibility of informing their employees on hour to improve their job performance on an ongoing basis, and managing the management systems and resources that are designed to align the performance of employees in the restaurant section to the whole organisation (Aguinis et al., 2012; Ekaterini, 2011). Decision-making, performance feedback and training are the highest-rated management competencies (Toygar \& Akbulut, 2013).

Interpersonal domain: The interpersonal domain refers to those human skills needed to work effectively as a group member and/or to build co-operative effort within the teams that he / she leads. These human skills deal primarily with people and how individuals perceive one another within the organisation, as well as subsequent individual behaviours. They include understanding and motivating individuals as well as groups(Porter, 2005). Interpersonal competency skills relate to the ability to interact meaningfully with people at work. Skills include effective communication with fellow employees, thereby establishing strong interpersonal relations. Co-operative, satisfying relationships need to be forged among workgroup members (Lolli, 2013; Millar et al., 2010). Bailly and Léné (2012)define interpersonal skills as the ability to communicate effectively as well as the ability to harness employees' personality traits such as enthusiasm. Another aspect is the ability to interact socially and empathetically with customers. These traits are essential if waiters and workers in all types of restaurants, supermarkets, bank front-office services or call centres want to ensure success. Understanding customers' problems and seeing these from their perspective, serve to calm them to help them to solve their problems, while simultaneously being aware of the organisation's performance requirements through effective communication.

Intrapersonal domain: Intrapersonal skills refer to dimensions such as self-regard, emotional awareness, assertiveness, independence and self-actualisation (Bardzil \& Slaski, 2003; Wolfe, Phillips, \& Asperin, 2014), intellectual openness, a strong work ethic/conscientiousness and honest core self-evaluation (Hamilton, Symonds, \& Kotamraju, 2013). These feelings, thoughts and emotions are not readily observed because they exist within a person, therefore even an individual in close proximity may not be aware of these skills. People with intrapersonal intelligence are generally quiet and prudent, self-reflective and self-motivated. While being able to work unsupervised, they manage their personal growth and often engage in a search for identity (Vijayalakshmi, 2016). According to Ilkowska and Engle (2010) the acquisition of intrapersonal skills entails a process which monitors and directs attention, while maintaining and modifying behaviours to achieve a desired goal. Intrapersonal skills include traits such as flexibility, resourcefulness, self-esteem, goal-setting, taking the initiative, self-awareness and critical thinking (Vijayalakshmi, 2016), in addition to optimism, positive thinking, perseverance, commitment and tolerance (Bharwani \& Jauhari, 2013). Time-management, that is another dimension of intrapersonal skills, is rated as the most highly desired competency by seniorlevel hotel managers. Good time-management skills include coping effectively with multiple demands and priorities, managing time to ensure productivity and allocating sufficient time to cardinal issues (ChungHerra, Enz, \& Lankau, 2003).

Technical domain: Studies support the concept that the two most basic competencies needed by restaurant employees are technical, also known as 'hard skills', and 'soft skills' (Wikle \& Fagin, 2015). Technical skills are specialised levels of proficiency needed to complete a specific task or series of tasks, while 'soft skills' include 
competencies such as effective communication, which are important when working in the hospitality industry, especially when it comes to delegating duties or tasks. Technical skills are generally acquired through education, training and/or experience. Technical skills are the primary concern of employers when recruiting prospective employees, because these constitute the foundations of the job itself, that can be learnt both at school and on the job. These skills are a requirement for entry-level restaurant managers who need to calculate food costs in a restaurant, develop menus, possess culinary skills and have knowledge of food processes, serving methods and etiquette (Bailly \& Léné, 2012; Weber, Crawford, Lee, \& Dennison, 2013). Technical skills improve employability of hospitality graduates significantly (Wang \& Tsai, 2014). Development of food and beverage skills is perceived to be a stepping stone towards the application of general management skills(Baum, 2002).

Generations: A generation cohort describes a group of people of similar age, with similar attitudes, values and behaviour as distinct from those in other generation cohorts (Benckendorff, Moscardo, \& Pendergast, 2010). Around thirty years ago management in the hospitality industry focused on the expectations of the Baby Boomers and Generation X. Currently the Baby Boomers are leaving the workforce and Generation X employees are moving into middle and senior leadership positions with the Generation $Y$ (also referred to as Millennials) employees filing the positions of supervisors (first-line management) (Chi et al., 2013). This shift in the composition of the workforce is forcing management to gain explicit knowledge about what motivates Generation Y employees(Brown et al., 2015).Three generations are represented in today's workforce: Baby boomers (born between 1946 and1964), Generation Xers (born between 1965 and 1980) and Millennials (born between 1981 and 2000) (Chi et al., 2013). There will always be generational differences in perspectives, attitudes and behaviour. However, studies indicate that there are fundamental and major differences in the work values of the three generations presently in the hospitality workforce (Chen \& Choi, 2008). Gradually members of the younger generation (Millennials) are filling managerial positions vacated by Baby Boomers and Generation Xers. Therefore, it is important, from a managerial point of view, to recognise gaps that could create difficulties in the workplace. Ignoring generational differences will inevitably render an organisation less efficient (Govitvatana, 2001).

Baby boomers who were raised in an era of extreme optimism, opportunity and progress (Chi et al., 2013) grew up in the relative economic prosperity and stability of the post -World War II period (Park \& Gursoy, 2012). They perceive work as a much more important part of life than the attitude of younger generations (Park \& Gursoy, 2012). Loyalty and commitment to their organisations are highly valued (Gursoy, Maier, \& Chi, 2008). Generation Xers grew up in the end of the Cold War period when a number of economic recessions occurred during which times unemployment and family relocations were caused by economic instability (Twenge, Campbell, Hoffman, \& Lance, 2010). Gen Xers who tend to be independent place more value on their own careers than on loyalty to an organization. They link autonomy and freedom from supervision in the workplace to a strong desire for rapid career advancement (Park \& Gursoy, 2012).The Generation Y employee has a radically different work-related value structure and attitude from that of previous generations (Baby boomers and Generation X). They seek flexibility with regard to new experiences; they are prepared to move from project to project and/or expect to be given the opportunity to work in different locations. A strong characteristic of Generation Y employees is that they have a sense of urgency, which means that they care only about today and as they are not concerned about the future (Richardson, 2010). Generation Y employees are described as demanding individuals (Solnet \& Hood, 2008) who are generally less satisfied with their jobs (Earle, 2003)less engaged in their work and far less committed to the organisation that they work for.

Since employees from the same generation are likely to share similar norms, their work values and attitude toward work are likely to be influenced by the generation to which they belong. People from different generations could have difficulty in understanding others' perspectives in terms of work. This can be stressful and frustrating, causing confusion in the workplace (Gursoy et al., 2008). The younger generation value freedom and have high leisure/work values (Twenge et al., 2010) with disproportionately high expectations of promotion (Dannar, 2013) and pay rises in the workplace (Park \& Gursoy, 2012). They are confident players in businesses, financial institutions and governmental agencies. As they prefer a structured environment with clear rules, they are comfortable in a hierarchical organisation. However, they do want their jobs to be meaningful and they want to be respected (Dannar, 2013), as fairness and recognition are 
work values which they embrace (Chi et al., 2013). Millennials are often seen as warm and outgoing, adaptable and sensitive (Hertzman, Moreo, \& Wiener, 2015). In this study chronological age is used and respondents are categorised into 3 groups according to age. Hospitality establishments are faced not only with a diverse workforce in terms of gender, marital status, physical ability and language, but also with three generations (age groups): The Baby Boomers, Generation Xers and Generation Yers (Chi et al., 2013; Smit, Cronje, Brevis, \& Vrba, 2011; Yu \& Miller, 2005).

The youngest employees (Generation Yers) are becoming more numerous in the workplace while employing a hospitality employee with the required competencies is becoming an increasingly difficult task. These employees comprise a generation with different career expectations and aspirations from the other two generations (Baby Boomers and Generation Xers). The Generation Y employee expects so much to happen so quickly that hospitality managers have been caught totally off guard with regard to the new approach to work and expectations (Maxwell, Ogden, \& Broadbridge, 2010; Richardson \& Thomas, 2012). These Generation Yers are not just comfortable with technology, it is an integral part of their daily lives (Dannar, 2013).Tomorrow's restaurant managers or leaders need to possess skills and competencies that will enable establishments to remain competitive in the industry (Chung-Herra et al., 2003). The restaurant industry requires not only managers and employees with cross-domain abilities, it needs knowledgeable and competent staff that take cognisance of industrial trends and demands. Research suggests that supervisors often rely on "gut feeling", speculation and their own limited experience regarding those key factors that will ensure ongoing innovation in the restaurant industry. Literature advises that hospitality establishments adopt a hire-for-skill, as well as a train-for-skill approach to gain a competitive edge in the industry (Chang, Gong, \& Shum, 2011).

\section{Methodology}

The objective of the study was to determine which differences existed in different age groups regarding the perception of managerial competencies. The research design used for this study ensured that the information collected could provide answers to the research question, as well as resolve the hypotheses and meet the objectives of the paper that were formulated to address the question at hand. For the purposes of this study, the following hypotheses were formulated:

$\mathrm{H}_{01}$ - No significant differences exist in the different age groups' perceptions of the importance of the leadership domain.

$\mathrm{H}_{02}$ - No significant differences exist in the different age groups' perceptions of the importance of the management domain.

$\mathrm{H}_{03}$ - No significant differences exist in the different age groups' perceptions of the importance of the interpersonal domain.

$\mathrm{H}_{04}$ - No significant differences exist in the different age groups' perceptions of the importance of the intrapersonal domain.

$\mathrm{H}_{05}$ : - No significant differences exist in the perceptions of the different age groups' regarding the importance of the technical skills domain

Population and sample: A list of all the casual dining restaurants in the City of Tshwane (South Africa) was obtained from the Eat- out website which lists all restaurants in a specific area (Eat-out, 2014). The restaurants that met the criteria as casual dining restaurants were contacted telephonically. Of the 87 restaurants that were contacted via telephone and personal visits, only 47 agreed to participate in the study. The population consisted of 350 employees in the different restaurants $(\mathrm{N}=350)$. Questionnaires were distributed to all the restaurant employees in the identified restaurants. Only 180 employees $(n=180)$ completed the questionnaires, resulting in a response rate of $51 \%$, which is acceptable according to research standards (Mbithi, 2011).

Measuring instrument: Questionnaires were used as the main data gathering instrument for this study. The instrument employed in this study was created using the Competency Domain Model developed by Sandwith (1993). According to several authors(Millar et al., 2010; Porter, 2005), it is the most reliable and influential competency model in today's business environment, as it classifies competencies into five domains: leadership domain, conceptual domain, interpersonal domain, administrative domain and technical domain. 
Management and intrapersonal domains are often added to management competencies. In this paper the results from the management, leadership, interpersonal, intrapersonal and technical competency domains will be reported. The basic step in formulating the questions was to identify the required competencies, each question focused on a different competency domain which was broken down into skills. The questionnaire consists out of 46 six questions which was structured using a four- point Likert scale. This scale was used to measure respondents' perceptions as to which skills from the competency domains reviewed in the literature were deemed more important than others. Responses ranged from 1. Not important (NI), 2. Sometimes important (SI), 3. Important (I), to 4. Highly important (HI).

Data collection: A pilot study was conducted using a convenience sample of employees from two restaurants that were not included in the final study sample. Respondents were grouped into 3 age groups, 16-24 years, 25-40 years and above 40 . The study was done in an ethically responsible manner. Permission was obtained from the university's Faculty of Management Sciences. In this study, ethical procedures were followed (Mbithi, 2011),to address the following categories: informed consent, confidentiality and benefits to the industry.

Data analysis: Microsoft Excel@ 2010 STATA V12 statistical software was used to process the data from the completed questionnaires. Responses to the research questions were gathered and presented using descriptive statistical percentages for frequencies. To statistically analyse the sample, the Fisher's Exact test was conducted to test for significance. Cronbach's alpha was used to test internal consistency. In this study, the test score for each competency domain was 0.60 or above. Although researchers prefer a score of 0.70 , Mbithi (2011) and Yayha and Elsayed (2012) point out that a Cronbach's alpha of 0.60, although moderate, is acceptable.

\section{Results and discussion}

Significant differences were found in several of the managerial domains. The overall data analysis showed that all three generational age groups regarded most of the managerial competencies as sometimes important, important or highly important.

Table 1: Differences in age groups of their perceptions of the leadership domain

\begin{tabular}{|c|c|c|c|c|c|}
\hline \multirow[t]{2}{*}{ Variable } & \multirow[t]{2}{*}{ Four-point scale } & \multicolumn{3}{|c|}{ Age group } & \multirow{2}{*}{$\begin{array}{l}\text { Results of } \\
\text { Fisher exact } \\
\text { test }\end{array}$} \\
\hline & & $16-24$ & $25-40$ & $>40$ & \\
\hline \multirow{4}{*}{$\begin{array}{l}\text { Ability to motivate employees } \\
\text { to be productive }\end{array}$} & Highly important & 80.0 & 85.71 & 79.34 & \multirow[t]{4}{*}{0.651} \\
\hline & Important & 10.0 & 12.24 & 15.70 & \\
\hline & Sometimes important & 10.0 & 2.04 & 2.48 & \\
\hline & Not important & 0.0 & 0.0 & 2.48 & \\
\hline \multirow{3}{*}{$\begin{array}{l}\text { Ability to create a conducive } \\
\text { working environment }\end{array}$} & Highly important & 90.0 & 93.88 & 95.87 & \multirow[t]{3}{*}{0.477} \\
\hline & Important & 10.0 & 4.08 & 2.04 & \\
\hline & $\begin{array}{l}\text { Sometimes important } \\
\text { Not important }\end{array}$ & 0.0 & 2.04 & 1.65 & \\
\hline \multirow{3}{*}{$\begin{array}{l}\text { Ability to share information } \\
\text { that would make employees' } \\
\text { jobs easier }\end{array}$} & Highly important & 100 & 93.88 & 90.91 & \multirow[t]{3}{*}{0.265} \\
\hline & Important & 0.0 & 2.04 & 8.26 & \\
\hline & $\begin{array}{l}\text { Sometimes important } \\
\text { Not important }\end{array}$ & 0.0 & 4.08 & 0.83 & \\
\hline \multirow{4}{*}{$\begin{array}{l}\text { Ability to teach employees to } \\
\text { see difficulties as problems } \\
\text { solved }\end{array}$} & Highly important & 100 & 87.76 & 92.56 & \multirow[t]{4}{*}{0.623} \\
\hline & Important & 0.0 & 8.16 & 4.96 & \\
\hline & Sometimes important & 0.0 & 2.04 & 2.48 & \\
\hline & Not important & 0.0 & 2.04 & 0.0 & \\
\hline \multirow{4}{*}{$\begin{array}{l}\text { Ability to get all employees } \\
\text { involved in decision-making }\end{array}$} & Highly important & 90.0 & 75.51 & 94.21 & \multirow[t]{4}{*}{0.010} \\
\hline & Important & 10.0.0.0 & 16.33 & 3.31 & \\
\hline & Sometimes important & 0.0 & 8.16 & 1.65 & \\
\hline & Not important & & 0.0 & 0.83 & \\
\hline
\end{tabular}




\begin{tabular}{|c|c|c|c|c|c|}
\hline \multicolumn{6}{|c|}{$\begin{array}{c}\text { Journal of Economics and Behavioral Studies (ISSN: 2220-6140) } \\
\text { Vol. 10, No. 2, pp. 89-102, April } 2018 \\
\end{array}$} \\
\hline $\begin{array}{l}\text { Ability to grant employees an } \\
\text { opportunity to grow }\end{array}$ & $\begin{array}{l}\text { Highly important } \\
\text { Important } \\
\text { Sometimes important } \\
\text { Not important }\end{array}$ & $\begin{array}{l}100 \\
0.0 \\
0.0 \\
0.0\end{array}$ & $\begin{array}{l}75.51 \\
16.33 \\
6.12 \\
2.04\end{array}$ & $\begin{array}{l}94.21 \\
4.96 \\
0.83 \\
0.0\end{array}$ & 0.013 \\
\hline $\begin{array}{l}\text { Ability to instil employees' } \\
\text { work commitment }\end{array}$ & $\begin{array}{l}\text { Highly important } \\
\text { Important } \\
\text { Sometimes important } \\
\text { Not important }\end{array}$ & $\begin{array}{l}90.0 \\
10.0 \\
0.00\end{array}$ & $\begin{array}{l}85.71 \\
12.24 \\
\\
2.04\end{array}$ & $\begin{array}{l}95.04 \\
4.96 \\
0.00\end{array}$ & 0.119 \\
\hline $\begin{array}{l}\text { Ability to inspire employees } \\
\text { with new ideas }\end{array}$ & $\begin{array}{l}\text { Highly important } \\
\text { Important } \\
\text { Sometimes important } \\
\text { Not important }\end{array}$ & $\begin{array}{l}100 \\
0.00 \\
0.00 \\
0.00\end{array}$ & $\begin{array}{l}75.51 \\
18.37 \\
4.08 \\
2.04\end{array}$ & $\begin{array}{l}90.91 \\
7.44 \\
0.83 \\
0.83\end{array}$ & 0.108 \\
\hline $\begin{array}{l}\text { Ability to provide employees } \\
\text { with personal attention }\end{array}$ & $\begin{array}{l}\text { Highly important } \\
\text { Important } \\
\text { Sometimes important } \\
\text { Not important }\end{array}$ & $\begin{array}{l}100 \\
0.00 \\
0.00 \\
0.00\end{array}$ & $\begin{array}{l}71.43 \\
16.33 \\
10.20 \\
2.04\end{array}$ & $\begin{array}{l}91.74 \\
4.96 \\
3.31 \\
0.00\end{array}$ & 0.018 \\
\hline Ability to promote teamwork & $\begin{array}{l}\text { Highly important } \\
\text { Important } \\
\text { Sometimes important } \\
\text { Not important }\end{array}$ & $\begin{array}{l}90.0 \\
10.0 \\
0.00 \\
0.00\end{array}$ & $\begin{array}{l}83.67 \\
6.12 \\
4.08 \\
6.12 \\
\end{array}$ & $\begin{array}{l}86.78 \\
6.61 \\
4.13 \\
2.48 \\
\end{array}$ & 0.838 \\
\hline
\end{tabular}

Table 2: Differences in age groups of their perceptions of the management domain

\begin{tabular}{|c|c|c|c|c|c|}
\hline \multirow[t]{2}{*}{ Variable } & \multirow[t]{2}{*}{ Four-point scale } & \multicolumn{3}{|c|}{ Age group } & \multirow{2}{*}{$\begin{array}{l}\text { Results of } \\
\text { Fisher exact } \\
\text { test }\end{array}$} \\
\hline & & $16-24$ & $25-40$ & $>40$ & \\
\hline \multirow{4}{*}{$\begin{array}{l}\text { Employee training and } \\
\text { development }\end{array}$} & Highly important & 90.0 & 83.67 & 89.26 & \multirow[t]{4}{*}{0.169} \\
\hline & Important & 0.00 & 12.24 & 9.92 & \\
\hline & Sometimes important & 10.0 & 2.04 & 0.83 & \\
\hline & Not important & 0.00 & 2.04 & 0.00 & \\
\hline \multirow[t]{4}{*}{ Employee mentoring } & Highly important & 90.0 & 77.55 & 85.95 & \multirow[t]{4}{*}{0.565} \\
\hline & Important & 10.0 & 16.33 & 9.92 & \\
\hline & Sometimes important & 0.00 & 2.04 & 0.83 & \\
\hline & Not important & 0.00 & 4.08 & 3.31 & \\
\hline \multirow[t]{4}{*}{ Employee coaching } & Highly important & 90.0 & 79.59 & 86.7 & \multirow[t]{4}{*}{0.854} \\
\hline & Important & 10.0 & 12.24 & 7.44 & \\
\hline & Sometimes important & 0.00 & 4.08 & 3.31 & \\
\hline & Not important & 0.00 & 4.08 & 2.48 & \\
\hline \multirow{4}{*}{$\begin{array}{l}\text { Promotion of participative } \\
\text { decision-making }\end{array}$} & Highly important & 80.010 .0 & 83.67 & 87.60 & \multirow[t]{4}{*}{0.074} \\
\hline & Important & 10.0 & 12.24 & 8.26 & \\
\hline & Sometimes important & 0.00 & 4.08 & 0.00 & \\
\hline & Not important & & 0.00 & 4.13 & \\
\hline \multirow{4}{*}{$\begin{array}{l}\text { Promotion of feedback on } \\
\text { employee performance }\end{array}$} & Highly important & 70.0 & 79.59 & 90.08 & \multirow[t]{4}{*}{0.030} \\
\hline & Important & 30.00 .00 & 12.24 & 3.31 & \\
\hline & Sometimes important & 0.00 & 8.16 & 4.96 & \\
\hline & Not important & & 0.00 & 1.65 & \\
\hline \multirow{4}{*}{$\begin{array}{l}\text { Promotion of employee } \\
\text { empowerment programmes }\end{array}$} & Highly important & 90.0 & 85.71 & 90.08 & \multirow[t]{4}{*}{0.652} \\
\hline & Important & 10.0 & 10.20 & 8.26 & \\
\hline & Sometimes important & 0.00 & 4.08 & 0.83 & \\
\hline & Not important & 0.00 & 0.00 & 0.83 & \\
\hline \multirow{4}{*}{$\begin{array}{l}\text { Ability to maintain discipline } \\
\text { in the workforce }\end{array}$} & Highly important & 70.0 & 83.67 & 93.39 & \multirow[t]{4}{*}{0.023} \\
\hline & Important & 10.0 & 6.12 & 4.13 & \\
\hline & Sometimes important & 10.0 & 2.04 & 0.83 & \\
\hline & Not important & 10.0 & 8.16 & 1.65 & \\
\hline
\end{tabular}


Table 3: Differences in age groups of their perceptions of the Interpersonal domain

\begin{tabular}{|c|c|c|c|c|c|}
\hline \multirow[t]{2}{*}{ Variable } & \multirow[t]{2}{*}{ Four-point scale } & \multicolumn{3}{|c|}{ Age group \% } & \multirow{2}{*}{$\begin{array}{l}\text { Results of } \\
\text { Fisher's exact } \\
\text { test }\end{array}$} \\
\hline & & $16-24$ & $25-40$ & $>40$ & \\
\hline \multirow{4}{*}{$\begin{array}{l}\text { Telephone communication } \\
\text { skills }\end{array}$} & Highly important & 100 & 77.55 & 89.26 & \multirow[t]{4}{*}{0.376} \\
\hline & Important & 0.00 & 14.29 & 5.79 & \\
\hline & Sometimes important & 0.00 & 6.12 & 4.13 & \\
\hline & Not important & 0.00 & 2.04 & 0.83 & \\
\hline \multirow[t]{4}{*}{ Listening skills } & Highly important & 90.0 & 81.63 & 91.74 & \multirow[t]{4}{*}{0.174} \\
\hline & Important & 0.00 & 10.20 & 2.48 & \\
\hline & Sometimes important & 10.0 & 6.12 & 2.48 & \\
\hline & Not important & 0.00 & 2.04 & 3.31 & \\
\hline \multirow[t]{4}{*}{ Writing skills } & Highly important & 90.0 & 85.71 & 86.78 & \multirow[t]{4}{*}{0.965} \\
\hline & Important & 10.0 & 8.16 & 9.09 & \\
\hline & Sometimes important & 0.00 & 2.04 & 1.65 & \\
\hline & Not important & 0.00 & 4.08 & 2.48 & \\
\hline \multirow[t]{4}{*}{ Customer service skills } & Highly important & 100 & 87.76 & 93.39 & \multirow[t]{4}{*}{0.644} \\
\hline & Important & 0.00 & 8.16 & 2.48 & \\
\hline & Sometimes important & 0.00 & 2.04 & 2.48 & \\
\hline & Not important & 0.00 & 2.04 & 1.65 & \\
\hline \multirow[t]{4}{*}{ Negotiation skills } & Highly important & 100 & 83.67 & 93.39 & \multirow[t]{4}{*}{0.095} \\
\hline & Important & 0.00 & 6.12 & 5.79 & \\
\hline & Sometimes important & 0.00 & 4.08 & 0.83 & \\
\hline & Not important & 0.00 & 6.12 & 0.00 & \\
\hline \multirow[t]{4}{*}{ Conflict management skills } & Highly important & 100 & 73.47 & 89.26 & \multirow{4}{*}{0.028} \\
\hline & Important & 0.00 & 20.41 & 6.61 & \\
\hline & Sometimes important & 0.00 & 2.04 & 4.13 & \\
\hline & Not important & 0.00 & 4.08 & 0.00 & \\
\hline
\end{tabular}

Table 4: Differences in age groups of their perceptions of the Intrapersonal domain

\begin{tabular}{|c|c|c|c|c|c|}
\hline \multirow[t]{2}{*}{ Variable } & \multirow[t]{2}{*}{ Four-point scale } & \multicolumn{3}{|c|}{ Age group \% } & \multirow{2}{*}{$\begin{array}{l}\text { Results of } \\
\text { Fisher's exact } \\
\text { test }\end{array}$} \\
\hline & & $16-24$ & $5-40$ & $>40$ & \\
\hline \multirow{4}{*}{ Ability to solve problems } & Highly important & 90.0 & 91.84 & 90.08 & 0.016 \\
\hline & Important & 10.0 & 0.00 & 9.09 & \\
\hline & Sometimes important & 0.00 & 2.04 & 0.83 & \\
\hline & Not important & 0.00 & 6.12 & 0.00 & \\
\hline \multirow[t]{4}{*}{ Ability to manage time } & Highly important & 100 & 79.59 & 92.56 & 0.069 \\
\hline & Important & 0.00 & 18.37 & 4.13 & \\
\hline & Sometimes important & 0.00 & 0.00 & 1.65 & \\
\hline & Not important & 0.00 & 2.04 & 1.65 & \\
\hline \multirow[t]{4}{*}{ Ability to adapt to change } & Highly important & 100 & 91.84 & 90.91 & 0.977 \\
\hline & Important & 0.00 & 4.08 & 4.96 & \\
\hline & Sometimes important & 0.00 & 2.04 & 3.31 & \\
\hline & Not important & 0.00 & 2.04 & 0.83 & \\
\hline \multirow[t]{4}{*}{ Ability to manage stress } & Highly important & 90.0 & 81.63 & 92.56 & 0.149 \\
\hline & Important & 10.0 & 18.37 & 6.61 & \\
\hline & Sometimes important & 0.00 & 0.00 & 0.00 & \\
\hline & Not important & 0.00 & 0.00 & 0.83 & \\
\hline \multirow[t]{4}{*}{ Ability to be creative } & Highly important & 100 & 93.88 & 91.74 & 0.740 \\
\hline & Important & 0.00 & 4.08 & 7.44 & \\
\hline & Sometimes important & 0.00 & 2.04 & 0.83 & \\
\hline & Not important & 0.00 & 0.00 & 0.00 & \\
\hline
\end{tabular}


Table 5: Differences in age groups of their perceptions of the Technical domain

\begin{tabular}{|c|c|c|c|c|c|}
\hline \multirow[t]{2}{*}{ Variable } & \multirow[t]{2}{*}{ Four-point scale } & \multicolumn{3}{|c|}{ Age group } & \multirow{2}{*}{$\begin{array}{l}\text { Results of } \\
\text { Fisher exact }\end{array}$} \\
\hline & & $16-242$ & $-40>$ & & \\
\hline \multirow[t]{3}{*}{ Culinary skills } & Highly important & 100 & 91.84 & 91.74 & 0.878 \\
\hline & Important & 0.00 & 6.12 & 4.13 & \\
\hline & $\begin{array}{l}\text { Sometimes important } \\
\text { Not important }\end{array}$ & 0.00 & 2.04 & 4.13 & \\
\hline \multirow[t]{4}{*}{ Menu planning skills } & Highly important & 100 & 89.80 & 91.74 & 0.630 \\
\hline & Important & 0.00 & 10.20 & 4.96 & \\
\hline & Sometimes important & 0.00 & 0.00 & 1.65 & \\
\hline & Not important & 0.00 & 0.00 & 1.65 & \\
\hline \multirow[t]{3}{*}{ Food presentation skills } & Highly important & 90.0 & 89.80 & 95.87 & 0.218 \\
\hline & Important & 10.0 & 8.16 & 4.13 & \\
\hline & $\begin{array}{l}\text { Sometimes important } \\
\text { Not important }\end{array}$ & 0.00 & 2.04 & 0.00 & \\
\hline \multirow[t]{3}{*}{ Knowledge on food products } & Highly important & 100 & 91.84 & 95.87 & 0.404 \\
\hline & Important & 0.000 .00 & 6.12 & 4.13 & \\
\hline & $\begin{array}{l}\text { Sometimes important } \\
\text { Not important }\end{array}$ & & 2.04 & 0.00 & \\
\hline \multirow{4}{*}{$\begin{array}{l}\text { Knowledge } \\
\text { procedures }\end{array}$} & Highly important & 100 & 95.92 & 95.04 & 0.614 \\
\hline & Important & 0.00 & 2.04 & 4.13 & \\
\hline & Sometimes important & 0.00 & 0.00 & 0.83 & \\
\hline & Not important & 0.00 & 2.04 & 0.00 & \\
\hline Knowledge in & Highly important & 100 & 91.84 & 95.04 & 0.709 \\
\hline \multirow[t]{3}{*}{ kitchen equipment } & Important & 0.00 & 8.16 & 4.96 & \\
\hline & Sometimes important & & & & \\
\hline & Not important & & & & \\
\hline \multirow[t]{3}{*}{ Ability to control food wastage } & Highly important & 90.0 & 95.92 & 93.39 & 0.733 \\
\hline & Important & 10.0 & 4.08 & 5.79 & \\
\hline & $\begin{array}{l}\text { Sometimes important } \\
\text { Not important }\end{array}$ & 0.00 & 0.00 & 0.83 & \\
\hline
\end{tabular}

Managers and employees place a high importance on leadership skills (Suh et al., 2012). For the leadership domain (Table 1), significantly fewer $(p=0.010)$ respondents aged $25-40$ perceived the ability to get all employees involved in decision-making as highly important. Significantly more $(\mathrm{p}=0.013)$ young respondents $(16-24)$ and older respondents ( $>40)$ perceived the ability to grant employees an opportunity to grow as highly important compared to respondents aged 25-40. All respondents in the age group 16-24 years perceived this as highly important. Significantly fewer $(\mathrm{p}=0.018)$ respondents aged $25-40$ perceived the ability to provide employees with personal attention as highly important compared to the younger group and respondents older than 40 years. For all the domains where significant differences were documented the respondents aged 25-40 were less likely to perceive a domain as highly important. The importance of teamwork for the younger generations is emphasised by researchers such as Gursoy et al. (2008)and Jiang and Alexakis (2017).The ability to promote teamwork was also highly important or important to the younger restaurant employees. Several studies highlighted the importance of managerial competencies in the hospitality industry (Jiang \& Alexakis, 2017; Suh et al., 2012).The proportion of those who considered the promotion of feedback on employee performance to be highly important was significantly higher $(\mathrm{p}=0.030)$ for the oldest age group ( $>40)$ than for the youngest respondents (16-24) (Table 2). Only a small proportion regarded it as not important, and they were in the group aged over 40 . The ability to maintain discipline in the workforce was perceived by significantly more $(\mathrm{p}=0.023)$ respondents in the oldest category $(>40)$ as highly important, than by respondents in the youngest category (16-24). According to Twenge et al. (2010), the younger generation value freedom. Differences in attitude towards authority ranged from accepting, questioning to even rebelling against traditional viewpoints and orders handed down from managers (Gursoy et al., 2008). 
The importance of interpersonal skills is a confirmation of Suh et al. (2012)' results. All the skills categories in the interpersonal domain were rated as important by all the age categories, especially by the youngest employees (Table 3). All respondents in this age category indicated that telephone communication skills, customer service skills, negotiation skills and conflict management skills were highly important. Jiang and Alexakis (2017) reported that oral communication skills are perceived by managers to be one of the three most important management domains in the hospitality industry. However, it is a concern that the writing and listening skills categories which are deemed so important by Christou (2002) and Tesone and Ricci (2006)were perceived by only a small percentage (10\%) of 16-24 year olds as important. The 25-40 year olds perceived all the interpersonal skills categories as less important when compared to the ratings of the other two age groups. There was a significant difference $(p=0.028)$ in the perceptions of the different age groups regarding conflict management. The 25-40 year olds perceived conflict management as less important when compared to the other two age groups. Welch and Mickelson (2013) agree with findings of this study that listening is an important human resource skill to ensure effective restaurant operation and it assumes increasing importance as employees rise to managerial status and gain experience.

The intrapersonal skills categories (Table 4) were rated as very important by all the groups as only a limited number of respondents indicated that these were not important. Youngest respondents perceived all the intrapersonal categories as highly important. However, the ability to solve problems and the ability to manage stress were perceived by only $10 \%$ of respondents as important. Significantly more respondents $(p=0.016)$ in the 25-40-year category perceived the ability to solve problems as not important, when compared to the ratings of the other two age categories. A study conducted by Toygar and Akbulut (2013) concludes that managers who feel committed to their organisations have high-level problem-solving, decision-making and creative skills. The ability to be creative was rated as the most important intrapersonal category by the $25-40$ year olds, whereas $93.88 \%$ of respondents perceived it as highly important. The ability to manage time and stress was perceived by the oldest age group as most important in the intrapersonal category. This is contradicted by Jiang and Alexakis (2017) who found that managers, who are normally in an older age group, rated time management as less important than the younger group. Suh et al. (2012) make the point that due to the fast-changing business environment in the restaurant industry, all managers and employees need to possess skills to adapt to change creatively, to handle stress calmly and to solve problems effectively.

In general, all age categories perceived the technical competencies (Table 5) needed to perform their duties as employees as highly important. There were no significant differences, although the youngest age group restaurant employees did rate most of the technical skills as highly important with two exceptions. Of these employees, $10 \%$ rated food presentation skills and the ability to control food wastage as important. With regard to culinary skills and menu-planning skills, the two older age groups rated these skills as highly important, important and sometimes important. Regarding menu planning, $10 \%$ of the $25-40$ year old employees rated these skills as important, whereas nearly $4 \%$ of the over- 40 age group perceived these skills as sometimes important or not important. Knowledge of operating kitchen equipment was rated as highly important by the youngest age group, whereas the two other age groups rated it as highly important or important. Zopiatis (2010) asserts that technical (culinary-specific) competencies, such as knowledge of food products, food preparation and presentation are considered most important in the restaurant sector. This proves that culinary skills are prerequisite at entry level for a manager or an employee. Food preparation and quality are key determinants of customer satisfaction and loyalty (Voon et al., 2013). Suh et al. (2012) maintain that knowledge of product, service and culinary skills are essential competencies in the hospitality industry. Prerequisites for entry-level restaurant managers are calculation of food costs in a restaurant, menu development, culinary skills, food processes, serving methods and etiquette. Suh et al. (2012), however, report that hospitality-related technical skills are deemed not very important to success in the hospitality industry.

\section{Conclusion}

Statistical differences were found in leadership domain items, therefore $\mathrm{H}_{01}$ that no significant differences exist in the different age groups' perceptions of the importance of the leadership domain is rejected. Evidence obtained for rejecting $\mathrm{H}_{02}(\mathrm{p}=\leq 0.05)$ shows that significant differences exist in the different age 
groups' perceptions of the importance of the management domain. The hypotheses testing indicated that no significant differences existed in the 3 age groups for 5 of the 6 interpersonal skills categories while significant differences existed in the variable "conflict management skills". Therefore, evidence has been produced for rejecting $\mathrm{H}_{03}(\mathrm{p}=\leq 0.05)$ that no significant differences exist in the different age groups' perceptions of the importance of the interpersonal domain in restaurants. The hypotheses testing further indicated that no significant differences existed in the 3 age groups for 4 of the 5 intrapersonal skills categories while there was a significant difference in the variable "Ability to solve problems". This provides evidence for rejecting $\mathrm{H}_{04}(\mathrm{p}=\leq 0.05)$ that no significant differences existed in the different age groups' perceptions of the importance of the intrapersonal domain in restaurants. $\mathrm{H}_{05}$, namely that no significant differences existed in the perceptions of the different age groups' regarding the importance of the technical skills needed to perform their duties as restaurant employees and as potential first-line managers was accepted.

Conflict could develop among different age groups if the ability to solve problems is not perceived by all employees as important. Employees from different age groups perceive the importance of managerial and leadership competencies differently. Employees from different age groups working together have both positive and negative impacts on the work environment, employee retention, service quality and company profitability. The restaurant industry relies increasingly on employee creativity and teamwork to ensure excellence in operations. Organisations of all kinds encourage team creativity so that they can compete more keenly. It could be concluded that most of the respondents in all age categories perceived most of the managerial competencies as either highly important or important. The 25-40 year olds perceived more of the competencies as sometimes important or not important compared to the youngest and oldest age groups. In general, the 16-24 year olds perceived the managerial competencies as more important than the other two age groups. Only when employees in all age groups are fully competent to perform their appointed tasks, will their level of job satisfaction increase with guaranteed positive outcomes for restaurants.

Recommendations: The value of this research is that it applies the existing knowledge of generations and managerial competencies in the restaurant industry. Training should be offered in line with competency needs. Compiling a complete set of managerial competency profiles will provide a comprehensive framework for the planning of training and development in an organisation. Training institutions should take note of the younger generation's perceptions regarding the importance of particular managerial competencies to support their needs. The tertiary education environment should be cognisant of the needs of industry, as well as the perceptions of different generations regarding the importance of managerial competencies. Students should be trained on what to expect from different generations in the workplace. This study contributes to ongoing research in the hospitality industry, without which it will not be possible to develop relevant curricula to ensure that graduates are employable. The curriculum should include informing hospitality students about the realities of the hospitality industry. Lecturers with relevant experience in industry are important to the success of hospitality students. Industry should also be informed about the perceptions of the different generations regarding the importance of managerial skills to ensure a work environment that is conducive to understanding both older and younger employees. From a managerial point of view, it is imperative to understand the value differences, as well as similarities, in a diverse workforce. Once these differences are understood, management will be able to formulate better strategies with regard to recruitment and employee retention. Due to the diversity and generational differences in the workforce, it is vital for hospitality organisations and their management teams to have an understanding of the work value differences as well as the similarities in older and younger employees.

\section{References}

Aguinis, H., Gottfredson, R. K. \& Joo, H. (2012). Delivering effective performance feedback: The strengthsbased approach. Business Horizons, 55(2), 105-111.

Bailly, F. \& Léné, A. (2012). The personification of the service labour process and the rise of soft skills: a French case study. Employee Relations, 35(1), 79-97.

Bardzil, P. \& Slaski, M. (2003). Emotional intelligence: Fundamental competencies for enhanced service provision. Managing Service Quality: An International Journal, 13(2), 97-104.

Baum, T. (2002). Skills and training for the hospitality sector: a review of issues. Journal of Vocational Education and Training, 54(3), 343-364. 
Benckendorff, P., Moscardo, G. \& Pendergast, D. (2010). Tourism and generation Y: Cabi.

Bharwani, S. \& Jauhari, V. (2013). An exploratory study of competencies required to co-create memorable customer experiences in the hospitality industry. International Journal of Contemporary Hospitality Management, 25(6), 823-843.

Brown, E. A., Thomas, N. J. \& Bosselman, R. H. (2015). Are they leaving or staying: A qualitative analysis of turnover issues for Generation $\mathrm{Y}$ hospitality employees with a hospitality education. International Journal of Hospitality Management, 46, 130-137.

Chang, S., Gong, Y. \& Shum, C. (2011). Promoting innovation in hospitality companies through human resource management practices. International Journal of Hospitality Management, 30(4), 812-818.

Chen, P. J.\& Choi, Y. (2008). Generational differences in work values: a study of hospitality management. International Journal of Contemporary Hospitality Management, 20(6), 595-615.

Cherniss, C. \& Goleman, D. (2001). The emotionally intelligent workplace. How to select for, measure and improve emotional intelligence in individuals, groups and organisations. EEUU: Copyright.

Chi, C. G., Maier, T. A. \& Gursoy, D. (2013). Employees' perceptions of younger and older managers by generation and job category. International Journal of Hospitality Management, 34, 42-50.

Christou, E. (2002). Revisiting competencies for hospitality management: Contemporary views of the stakeholders. Journal of Hospitality \& Tourism Education, 14(1), 25-32.

Chung-Herra, B., Enz, C. \& Lankau, M. (2003). Grooming Future Hospitality Leaders: A Competencies Model. Acquiring hotel-industry expertise pales in a future-oriented competencies model in favor of managers' ethical behavior and strategic-management acumen. Cornell Hotel and Restaurant Administration Quarterly, Human Resources, 3, 1-25.

Dannar, P. R. (2013). Millennials: What they offer our organizations and how leaders can make sure they deliver. The Journal of Values-Based Leadership, 6(1), 3.

Earle, H. A. (2003). Building a workplace of choice: Using the work environment to attract and retain top talent. Journal of Facilities Management, 2(3), 244-257.

Eat-out. (2014). Pretoria restaurants. Retrieved from www.eatout.co.za

Ekaterini, G. (2011). A qualitative approach to middle managers' competences. Management research review, 34(5), 553-575.

Firdauz, A., Sapri, M. \& Mohammad, I. (2015). Facility management knowledge development in Malaysia: Added value in hospitality managerial competency. Facilities, 33(1/2), 99-118.

Govitvatana, W. V. (2001). Generation gap in the workplace between baby boomers and generation X. Research Paper University of Wisconsin-Stout.

Gursoy, D., Maier, T. A. \& Chi, C. G. (2008). Generational differences: An examination of work values and generational gaps in the hospitality workforce. International Journal of Hospitality Management, 27(3), 448-458.

Hamilton, S., Symonds, W. \& Kotamraju, P. (2013). Career and Technical Education and New York State Regents Examinations: Committee Report.

Hertzman, J. L., Moreo, A. P. \& Wiener, P. J. (2015). Career planning strategies and skills of hospitality management students. Journal of Human Resources in Hospitality \& Tourism, 14(4), 423-443.

Ilkowska, M. \& Engle, R. W. (2010). Trait and state differences in working memory capacity Handbook of individual differences in cognition (pp. 295-320): Springer.

Jauhari, V. (2009). The hospitality and tourism industry in India: conclusions and solutions. Worldwide Hospitality and Tourism Themes, 1(1), 75-80.

Jiang, L. \& Alexakis, G. (2017). Comparing students' and managers' perceptions of essential entry-level management competencies in the hospitality industry: An empirical study. Journal of hospitality, leisure, sport \& tourism education, 20, 32-46.

Kalargyrou, V. \& Woods, R. H. (2011). Wanted: training competencies for the twenty-first century. International Journal of Contemporary Hospitality Management, 23(3), 361-376.

Kay, C.\& Russette, J. (2000). Hospitality-management competencies: Identifying managers' essential skills. Cornell hotel and restaurant administration quarterly, 41(2), 52-63.

Kim, N. (2014). Employee turnover intention among newcomers in travel industry. International Journal of Tourism Research, 16(1), 56-64.

Koenigsfeld, P. J., Perdue, J., Youn, H. \& Woods, R. H. (2011). The changing face of competencies for club managers. International Journal of Contemporary Hospitality Management, 23(7), 902-922. 
Koenigsfeld, P. J., Youn, H., Perdue, J. \& Woods, R. H. (2012). Revised competencies for private club managers. International Journal of Contemporary Hospitality Management, 24(7), 1066-1087.

Kowske, B. J., Rasch, R. \& Wiley, J. (2010). Millennials'(lack of) attitude problem: An empirical examination of generational effects on work attitudes. Journal of Business and Psychology, 25(2), 265-279.

Lolli, J. C. (2013). Interpersonal communication skills and the young hospitality leader: Are they prepared? International Journal of Hospitality Management, 32, 295-298.

Louw, L., Pearse, N. J. \& Dhaya, J. (2012). The role of experience in the development of social competencies. $S A$ Journal of Human Resource Management, 10(1), 9.

Mahachi, D. (2012). Students' Perceptions of Managerial Competencies: A Study of Undergraduate Tourism and Hospitality Students at the University of Botswana. Journal of Human Resources in Hospitality \& Tourism, 11(3), 239-258.

Maxwell, G. A., Ogden, S. M. \& Broadbridge, A. (2010). Generation Y's career expectations and aspirations: Engagement in the hospitality industry. Journal of Hospitality and Tourism Management, 17(1), 53-61.

Mbithi, M. K. (2011). Entrepreneurial Skills Among Business Owners in the Tshwane Metropolitan Municipality. Tshwane University of Technology.

McCarthy, A. M. \& Garavan, T. N. (2007). Understanding acceptance of multisource feedback for management development. Personnel Review, 36(6), 903-917.

McKenna, S. (2004). Predispositions and context in the development of managerial skills. Journal of Management Development, 23(7), 664-677.

Millar, M., Mao, Z. \& Moreo, P. (2010). Hospitality \& tourism educators vs. the industry: A competency assessment. Journal of Hospitality \& Tourism Education, 22(2), 38-50.

Neagu, 0., Lazar, V., Teodoru, M. \& Macarie, S. (2016). Human Capital Quality and Development: An Employers' and Employees' Comparative Insight. Studia Universitatis, Vasile Goldis Arad-Economics Series, 26(3), 62-73.

Park, J. \& Gursoy, D. (2012). Generation effects on work engagement among US hotel employees. International Journal of Hospitality Management, 31(4), 1195-1202.

Porter, J. D. (2005). Application of Sandwith's competency domain model for senior college housing officers in the United States. University of Florida.

Price Waterhouse Coopers. (2016). Rooms with an African view Hotels outlook: 2016-2020 South Africa Nigeria - Mauritius - Kenya - Tanzania

Richardson, S. (2010). Generation Y's perceptions and attitudes towards a career in tourism and hospitality. Journal of Human Resources in Hospitality \& Tourism, 9(2), 179-199.

Richardson, S. \& Thomas, N. J. (2012). Utilising generation Y: United States hospitality and tourism students' perceptions of careers in the industry. Journal of Hospitality and Tourism Management, 19(3).

Riggs, M. W. \& Hughey, A. W. (2011). Competing values in the culinary arts and hospitality industry: Leadership roles and managerial competencies. Industry and Higher Education, 25(2), 109-118.

Sandwith, P. (1993). A hierarchy of management training requirements: The competency domain model. Public Personnel Management, 22(1), 43-62.

Shai, M. P., Kleynhans, I. C. \& Roeloffze, A. (2016). Leadership competencies of restaurant managers in Pretoria, South Africa. Paper presented at the 2nd Global Tourism and Hospitality Conference, Hong Kong.

Singh, V. (2008). Managerial competencies in the restaurant industry: managers and subordinates perceptions. (MBA ), University of KwaZulu-Natal.

Sisson, L. G. \& Adams, A. R. (2013). Essential hospitality management competencies: The importance of soft skills. Journal of Hospitality \& Tourism Education, 25(3), 131-145.

Smit, P. J., Cronje, G. d., Brevis, T. \& Vrba, M. (2011). Management principles: a contemporary edition for Africa: Juta and Company Ltd.

Solnet, D. \& Hood, A. (2008). Generation Y as hospitality employees: Framing a research agenda. Journal of Hospitality and Tourism Management, 15(1), 59-68.

Streeter, B. (2007). Welcome to the new workplace. American Bankers Association. ABA Banking Journal, 99(12), 7.

Suh, E., West, J. J. \& Shin, J. (2012). Important competency requirements for managers in the hospitality industry. Journal of hospitality, leisure, sport \& tourism education, 11(2), 101-112.

Tesone, D. V. \& Ricci, P. (2006). Toward a definition of entry-level job competencies: Hospitality manager perspectives. International journal of hospitality \& tourism administration, 7(4), 65-80. 
Toygar, S. A. \& Akbulut, Y. (2013). Managerial Skills of hospital administrators: case study of Turkey. Journal of Health Management, 15(4), 579-594.

Twenge, J. M., Campbell, S. M., Hoffman, B. J. \& Lance, C. E. (2010). Generational differences in work values: Leisure and extrinsic values increasing, social and intrinsic values decreasing. Journal of management, 36(5), 1117-1142.

Vijayalakshmi, V. (2016). Soft Skills-The Need of the Hour for Professional Competence: A Review on Interpersonal Skills and Intrapersonal Skills Theories. International Journal of Applied Engineering Research, 11(4), 2859-2864.

Voon, B. H., de Jager, J., Chitra, K., Kueh, K. \& Jussem, P. M. (2013). Human service matters: a cross-national study in restaurant industry. Asian Journal of Business Research ISSN, 1178, 8933.

Wang, Y. F. \& Tsai, C. T. (2014). Employability of hospitality graduates: Student and industry perspectives. Journal of Hospitality \& Tourism Education, 26(3), 125-135.

Weber, M. R., Crawford, A., Lee, J. \& Dennison, D. (2013). An exploratory analysis of soft skill competencies needed for the hospitality industry. Journal of Human Resources in Hospitality \& Tourism, 12(4), 313332.

Weber, M. R., Finley, D. A., Crawford, A. \& Rivera, D. (2009). An exploratory study identifying soft skill competencies in entry-level managers. Tourism and hospitality Research, 9(4), 353-361.

Welch, S. \& Mickelson, W. T. (2013). A listening competence comparison of working professionals. International Journal of Listening, 27(2), 85-99.

Wikle, T. A. \& Fagin, T. D. (2015). Hard and soft skills in preparing GIS professionals: Comparing perceptions of employers and educators. Transactions in GIS, 19(5), 641-652.

Wolfe, K. L., Phillips, W. J. \& Asperin, A. (2014). Using hotel supervisors' emotional intelligence as a benchmark for hospitality students. Journal of Hospitality \& Tourism Education, 26(1), 2-9.

Yang, S. B. \& Guy, M. E. (2006). GenXers versus boomers: Work motivators and management implications. Public Performance \& Management Review, 29(3), 267-284.

Yayha, H. A. T. \& Elsayed, K. A. (2012). The influencing factors of managerial competencies among SMEs in Selangor, Malaysia: The results of quantitative study. Australian Journal Basic and Applied Sciences, 6(13), 111-122.

Yu, H. C. \& Miller, P. (2005). Leadership style: The X Generation and Baby Boomers compared in different cultural contexts. Leadership \& Organization Development Journal, 26(1), 35-50.

Zopiatis, A. (2010). Is it art or science? Chef's competencies for success. International Journal of Hospitality Management, 29(3), 459-467. 